\title{
Juridical Review of Chemical Castration Action In The Perspective of Criminal Law And Human Rights
}

\author{
Aulya Dwisudarini ${ }^{1}$, Muridah Isnawati ${ }^{2}$ \\ ${ }^{1}$ Faculty of Law, Muhammadiyah University of Surabaya \\ ${ }^{* 2}$ Law Lecturer, Muhammadiyah University of Surabaya \\ E-mail: ${ }^{1}$ adwisudarini@gmail.com
}

\begin{abstract}
Children are a gift from God Almighty must be maintained for their survival because children are the future and next generation of the nation. A state commits protecting the children's rights and ensuring children's welfare by issuing several laws and regulations accommodating all children's needs and rights. However, this have not reduce the case numbers of sexual violence against children yet, therefore, the government issued a new regulation, namely Law Number 17 of 2016 which regulates new sanctions for perpetrators of sexual violence and the addition of chemical castration. The purpose of this research is to find out the juridical review of chemical castration in the perspective of criminal law and human rights. The research method used in this research is normative jurisdiction using a law approach. The results of the study found that chemical castration is appropriate for perpetrators of sexual violence against children, because sexual violence against children is a serious, cruel crime. Chemical castration does not violate human rights because it aims to normalize the hormones of pedophiles and the rehabilitation carried out by medical experts is aimed at enabling pedophiles to be normal human beings physically and mentally.
\end{abstract}

Keywords: Action, Castration, Crime, Human Right

\section{INTRODUCTION}

Children are the most beautiful gift from God that must be maintained for their survival. Children are the nation's next generation and ideals future, which would continue national development in the future. Therefore, the country must be committed to protecting children's rights and ensuring children's welfare. The country's commitment to protect children's rights and ensure the welfare of children is formulated in the Constitution of the Republic of Indonesia of 1945 Article 28B paragraph (2) which stated, "Every child has the right to survive, grow and develop and has the right to for protection from violence and discrimination". To ensure the implementation of these commitments, Law Number 39 of 1999 on Human Rights has been ratified which includes the rights of children, implementation of the obligations and responsibilities of parents, family, community, government, and the state to provide protection for children, as well as Law Number 23 of 2002 on Child Protection which has been amended by Law Number 35 of 2014 on Amendments to Law Number 23 of 2002 of Child Protection. 
Although children's rights and protection have been guaranteed by the country, the crime of sexual violence against children is still rampant in society. One of the cases of sexual violence against children that shocked the world was the case of sexual intercourse and Yuyun's murdered.

Yuyun, 14 years old, was a student at SMP Negeri 5 Padang Ulak Tanding, who was killed and sexually assaulted on her way home from school in Kasie Kasubun Village, Padang Ulak Tanding District, Rejang Lebong Regency, Bengkulu. Yuyun was killed and raped by 14 people in turns. It should be noted that among the 14 perpetrators, four (4) of them are child perpetrators. (Yuliardi Hardjo Putro, 2016).

One month after her case, President Joko Widodo issued Government Regulation in Lieu of Law Number 1 of 2016 on the Second Amendment to Law Number 23 of 2002 on Child Protection. According to President Joko Widodo, it is intended to respond to the urgency caused by sexual violence against children which is increasing significantly. (BBC News, 2016). The Government Regulation in Lieu of Law Number 1 of 2016 was later ratified into Law Number 17 of 2016 on Stipulation of Government Regulation in Lieu of Law Number 1 of 2016 on the Second Amendment to Law Number 23 of 2002 on Child Protection.

On December 7, 2020, President Joko Widodo issued Government Regulation Number 70 of 2020 on the Procedures for the Implementation of Chemical Castration, Installation of Electronic Detection Devices, Rehabilitation, and Announcement of the Identity of Perpetrators of Sexual Violence Against Children. The chemical castration stage begins with a clinical assessment carried out by a team consisting of officers who have competence in medicine and psychiatry. The clinical assessment consists of clinical and psychiatric interviews, physical examination, and supporting examinations. The medical and psychiatry team then concludes the results of the clinical assessment to determine whether the perpetrator is eligible or not to be subjected to chemical castration. This conclusion is then presented to the Attorney General. If the results of the clinical assessment state that the perpetrator deserves chemical castration, then within a period of no later than 7 (seven) days from the receipt of the conclusion, the prosecutor commands the doctor to carry out chemical castration against the perpetrators of sexual violence against children. Chemical castration is carried out in a government-owned hospital or a designated hospital after the convict has finished serving the main sentence. (Fitria Chusna Farisa, 2021).

The enactment of Law Number 17 of 2016 on the Stipulation of Government Regulation in Lieu of Law Number 1 of 2016 and Government Regulation Number 70 of 2020 on the Procedures for Implementing Chemical Castration Measures, Installation of Electronic Detection Devices, Rehabilitation and Announcement of the Identity of Perpetrators of Sexual Violence Against Children, pros and cons emerged in the community, especially from the Indonesian Doctors Association and the National Human Rights Commission of the Republic of Indonesia. 
The Indonesian Doctors Association decided to find a way out for the issuance of these 2 (two) laws and regulations. According to the General Chair of the Indonesian Doctors Association, Daeng M. Faqih, chemical castration is a form of punishment, not a medical service. In accordance with Government Regulation Number 70 of 2020, if a doctor becomes the executor of chemical castration, it could be considered a violation of the Doctor's Oath and the Indonesian Medical Code of Ethics. (CNN Indonesia, 2021b).

The chemical castration also received controversy from the National Human Rights Commission of the Republic of Indonesia. According to the National Human Rights Commission of the Republic of Indonesia, chemical castration from the perspective of Human Rights is contrary to its rights and considered as human rights' robbed. The people in question is convicted of sexual violence against children. According to Beka Ulung Hapsara, Commissioner for Education and Counseling of the Indonesian National Human Rights Commission, it is against chemical castration since chemical castration is kind of torture and against human rights. (Komnas HAM RI, 2021).

The chemical castration action regulated in Law No. 17 of 2016 and Government Regulation No. 70 of 2020 is still getting pros and cons, especially from the Indonesian Doctors Association and the Indonesian National Human Rights Commission. According to the author, chemical castration is an interesting thing to be studied, researched, and the results of the research are written. Based on the description above, the authors are interested in researching and presenting the results of research on chemical castration in the form of a journal with the title: Juridical Review of Chemical Castration Action in the Perspective of Criminal Law and Human Rights.

The problem formulation in the journal entitled Juridical Review of Chemical Castration Action in the Perspective of Criminal Law and Human Rights are:

1. What is the juridical review of chemical castration action in the perspective of criminal law?

2. What is the juridical review of chemical castration action in the perspective of human rights?

The objectives to be achieved in this research journal, entitled Juridical Review of Chemical Castration Action in the Perspective of Criminal Law and Human Rights are:

1. To understand the juridical review of chemical castration action in the perspective of criminal law.

2. To understand the juridical review of chemical castration action in the perspective of human rights.

The research method used in this research journal is normative juridical using a statute approach. The normative juridical method is a research technique or procedure that is guided by 
several legal principles, legal rules, and legal principles relating to the substance of general and specific laws and regulations. (Mochamad Djunaedi, 2020)A statutory approach is an approach using legislation and regulations. The statute approach is carried out by reviewing all laws and regulations related to the legal issues being handled. The results of the study are an argument for solving the issues encountered. (Peter Mahmud Marzuki, 2017)

\section{RESULTS AND DISCUSSION}

\section{Juridical Review Of Chemical Castration Action In Criminal Law Perspective Definition Of Criminal Law}

Law is often understood as a set of rules made by the government and binds its citizens to the mechanism of the existence of sanctions as coercion to enforce the law. The government has the right to enforce sanctions against acts that violate the law where the perpetrator is declared guilty by a court that has permanent legal force. (Teguh Prasetyo, 2010).

The meaning of the term criminal law comes from the Netherlands. It is namely straafrecht, straaf. It means sanctions, criminal, punishment, while recht means law. According to a European legal expert, Pompe, who stated that criminal law is the entire set of legal provisions regarding punishable acts and their criminal rules. (Muridah Isnawati, 2018)

According to Didik Endro Purwoleksono, the term criminal is not the same as punishment. Punishment concerns civil, administrative and disciplinary matters. Based on the views of Muladi and Barda Nawawi Arief in their book "Theories of Criminal Policy", conclude that the characteristics of a criminal are (Didik Endro Purwoleksono, 2014) :

a. In essence it is an imposition of suffering or misery and suffering or other unpleasant consequences.

b. The punishment was given intentionally by the authority or the entitled institution.

c. The punishment is imposed on a person who has committed a crime according to the law.

\section{Definition Of Action (Maatregel)}

Actions (maatregel) include sanctions in criminal law. There is no term maatregel (action) in the Criminal Code. The actions intended to secure society and improve makers, such as forced education, forced treatment, admission to mental hospitals, and hand over to the parents. (Andi Hamzah, 2014).

The development of modern law recognizes the double-track system. It means the separation between criminal sanctions and action sanctions. The development of the legal system is what introduces action (maatregel) as another alternative to the main punishment, especially imprisonment. This happens due to the distrust of using "jail" for punishment/sanction. (Gita Santika, 2012). 
In the concept of the Criminal Code, actions are divided into two. There are actions given to whom are not able to take responsibility and whom are able to take responsibility imposed with the main criminal. Actions for people who are unable to take responsibility are:

a. treatment in mental hospitals;

b. submission to the government; or

c. hand over to someone.

There are actions for whom are capable of being responsible imposed with the main criminal (Gita Santika, 2012)

a. revocation of driving license;

b. deprivation of profits derived from criminal acts;

c. repairs due to criminal acts;

d. job training;

e. rehabilitation; and/or

f. care in the institution.

\section{Chemical Castration Actions In Criminal Perspective}

Sexual violence against children is increasing significantly day by day. It could threaten and endanger the children's lives, personal lives damage, and children's development, as well as the comfortability, peace, security, and public order harassment. Thus, it is appropriate if the government mentions that sexual violence against children is a crime against children (serious crimes).

Perceiving the sexual violence against children is increasing from time to time and the criminal sanctions imposed on perpetrators of sexual violence against children have not provided a deterrent effect and have not been able to comprehensively prevent the occurrence of sexual violence against children. Therefore, the Government passed Law Number 17 of 2016 on the Stipulation of Government Regulation in Lieu of Law Number 1 of 2016 on the Second Amendment to Law Number 23 of 2002 concerning Child Protection, which contains provisions that perpetrators of sexual violence against children in addition to being subject to a basic crime can also be subject to chemical castration. Chemical castration is an action carried out by injecting an anti-androgen (anti-testosterone) drug to perpetrators of sexual violence against children.

Provisions regarding chemical castration are contained in Article 81 and Article 81 A of Law Number 17 of 2016. There are the provisions for the chemical castration application as contained in Article 81 and Article 81 A of Law Number 17 of 2016:

1. Applied to perpetrators who have been convicted for committing a criminal act of violence or threats of violence forcing a child to have intercourse with him/her or with another person (residive). 
2. In the event that the criminal act as referred to in Article 76D of Law Number 35 of 2014 , causes more than one victim, serious injury, mental disorder, infectious disease, impaired or lost reproductive function, and/or the victim dies world.

3. The action of chemical castration should be decided together with the main punishment by specifying the period of action's execution.

4. Additional penalties and actions are excluded for child offenders.

5. The act of chemical castration is imposed for a maximum period of two years and is carried out after the convict has served the principal sentence.

6. The implementation of chemical castration is under periodic supervision by the ministry that carries out government affairs in the fields of law, social and health.

7. The implementation of chemical castration is accompanied by rehabilitation.

8. Further provisions regarding procedures for the implementation of chemical castration and rehabilitation are regulated in a Government Regulation.

A criminal expert at the Faculty of Law, Airlangga University, Amira Paripurna, believes that chemical castration is included in the category of anticipatory action sanctions to provide assistance so that the perpetrators of criminal acts could change better. Chemical castration should be carried out as a means of repairing the sexual desires of perpetrators of sexual violence against children to suppress sexual urges or criminal acts of sexual violence against children and not as a form of torture, but as an effort to recover from sexual disorders. According to Amira, chemical castration has three purposes of punishment based on the combination of theoretical perspective. (Andi Hamzah, 2014)The three objectives are (Nikmatus Sholikhah, 2021):

1. As a form of retaliation to the perpetrator as a result of the crime of sexual violence against children committed.

2. As a form of deterrence, providing a sense of security and order in society.

3. To restore sexual disorders suffered by the perpetrator.

According to the Professor of Criminal Law at the Faculty of Law, Airlangga University, Didik Endro Purwoleksono, chemical castration based on Law Number 17 of 2016 is very effective and could be imposed. This means if not every perpetrator of violence or perpetrators who use threats of violence to force children to have intercourse with her/him or other people could be subjected to chemical castration. This means that the government is serious about handling violent crimes whose victims are children, without compromising human rights. (Didik Endro Purwoleksono, 2019). In Article 81 Paragraph (7) of Law Number 17 the Year 2016, it is explicitly stated, "Against the perpetrators as referred to in Paragraph (4) and Paragraph (5) might be subjected to action of chemical castration and installation of electronic detection devices". Then, it shows some of the following: 
1. Chemical castration is not mandatory. It is left to the Assembly of Judges to decide whether or not to impose or be an alternative.

2. The task of the judges is to enforce the law and uphold justice.

The meaning of the sentence above is that the judge enforces the law, meaning that the judge is obliged to decide the case submitted to him, regardless of who is the perpetrator of the crime (equality before the law). The duty of the judge to uphold justice has consequences. The judge must consider mitigating and aggravating matters from the actions of the perpetrators of criminal acts (case by case). Thus, according to the judge's consideration, chemical castration needs to be imposed since it is the consequences of the accused perpetrator's action of violence or the defendant who uses the threat of violence to force the child having intercourse with him or with other people. It is legal if the judge makes a decision in the form of the chemical castration. (Didik Endro Purwoleksono, 2019)

Davide Cito stated "Although the abuse of minors by a Cleric is a particularly odious and very serious crime, it is certainly not the only crime contained in the delicta graviora. However, recent events have made this particular type of crime the driving force of reform, and in a sense, the central point in the Holy See's. (Davide Cito, 2011). Current penal legal system". Sexual violence against children is qualified as a graviora delicta or a serious, violent crime, as children are very vulnerable to being victims of crime and therefore must be given protection. Children as victims of sexual violence are affected tremendously, especially on their psychological development in the future, as a result of depression and shame.

According to Edward Omar Sharif Hiariej, Professor of Criminal Law, Faculty of Law, Gadjah Mada University, chemical castration for perpetrators of sexual violence against children is an appropriate punishment. Besides the perpetrators being unable to repeat their actions, at the same time chemical castration could become general prevention or efforts to prevent others from committing the same crime. (Edward Omar Sharif Hiariej, 2021)

The imposition of chemical castration follows the main punishment. This shows that chemical castration is not imposed independently. In other words, the defendant could not only be sentenced to chemical castration without imprisonment. The act of chemical castration is imposed for a maximum period of two years and carried out after the convict has served the principal sentence. This shows that chemical castration is not permanent. Thus, after the convict has finished undergoing chemical castration, it could still be restored to its original condition. (Didik Endro Purwoleksono, 2019)

\section{Juridical Review Of Chemical Castration Actions In Human Rights Perspective (Ham)}

The definition of human rights actually does not have a rigid norm that defines it as an interpretation of the meaning of human rights. However, according to the United Nations Human 
This work is licensed under a Creative Commons Attribution-ShareAlike 4.0 International License

Rights Office of the High Commission defines human rights as, "Human rights are rights inherent to all human beings, whatever our nationality, place of residence, sex, national or ethnic origin, colour, religion, language, or any other status. We are all equally entitled to our human rights without discrimination. These rights are all interrelated, interdependent and indivisible". (Satria Unggul Wicaksana Prakasa, 2017)

Human rights are a moral concept in the life of society and community. Its concept does not bear instantly and comprehensively. Human rights are born gradually and over time in the dynamics of human history. As a moral concept of human rights that is built and developed empirically in the life and interests of social life community. (Levina Yustitianingtyas, 2016)

Human rights are a material that is very attached to the essence and human life. The history of human rights could be traced to the beginning of the story of humans in their social life in this world. It is when they began to realize their position as legal subjects. However, according to science, the history of human rights only grows and develops when human rights are maintained and fought for by humans against attacks or dangers arising from the power possessed by the formation of society called nation. Hence, essentially the issue of human rights revolves around the relationship between individuals and society. (Nur Hafizal Hasanah dan Eko Soponyono, 2018)

\section{Chemical Castration Actions In Human Rights}

The number of cases of sexual violence against children has made the government understand if the problem of sexual crimes against children has reached an extraordinary point and extraordinary steps need to be taken to overcome this problem. Therefore, in the year of 2016 the Government issued Law Number 17 of 2016 of the Stipulation of a Substitute Government Regulation. Law Number 1 of 2016 about the Second Amendment to Law Number 23 of 2002 about Child Protection. Whereas in order to provide a deterrent effect on perpetrators of sexual violence against children, the law is added to provisions regarding chemical castration as contained in Article 81 Paragraph (7), "The perpetrators as referred to in Paragraph (4) and Paragraph (5) might be subject to action in the form of chemical castration and installation of electronic detection devices".

Chemical castration is the act of giving pills or injections of antiandrogen hormones. According to the Head of the Andrology and Sexology Section of the Faculty of Medicine, Udayana University, Denpasar, Wimpie Pangkahila, antiandrogen hormones are anti-male hormones. Giving antiandrogen drugs would make men lack testosterone so they don't have a sex drive. Antiandrogen drugs will have the same effect as physical castration. The administration of antiandrogen hormones also has an impact on physical health. The effects are reduced muscle tone, increased fat, resulting in reduced enthusiasm for life and enthusiasm for life, and cause bone 
loss in the long term. However, giving antiandrogen drugs would not have the effect that a man would become feminine. (Dian Maharani, 2015)

Indonesia is not the first country to apply chemical castration to perpetrators of sexual violence against children. Based on World Rape Statistics data or world statistics on cases of sexual intercourse in the world, there are 20 countries that impose chemical castration sanctions (CNN Indonesia, 2021a) :

1. England (enacted in 1950);

2. United States of America (enacted in 1996);

3. Poland (enacted in 2009)

4. Argentina (enacted in 2010, chemical castration is carried out voluntarily by perpetrators of sexual intercourse as a substitute for reduced sentences);

5. South Korea (enacted in 2011);

6. Russia (enacted in 2011)

7. Moldova (enacted in 2012, but in 2013 the regulation was repealed on grounds of human rights violations);

8. Kazakhstan (entered into force in 2018);

9. Ukraine (entered into force in July 2019);

10. Pakistan (enforced in 2020 for perpetrators of sexual intercourse and recidivist cases of sexual intercourse);

11. Estonia (unknown enacted year);

12. Israel (unknown enacted year);

13. Australia (unknown enacted year);

14. United Arab Emirates (unknown enacted year);

15. Czech Republic (unknown enacted year);

16. France (unknown enacted year);

17. Poland (unknown enacted year);

18. Macedonia (unknown enacted year);

19. Belgium (unknown enacted year);

20. Turkey (unknown enacted year);

The chemical castration, which has a long-term adverse effect on the body. Many people oppose it, especially the human rights activists. The National Human Rights Commission of the Republic of Indonesia is the one who oppose chemical castration since chemical castration is implied in torture and contrary to human rights. Beka Ulung Hapsara, Commissioner for Education and Counseling of the Indonesian National Human Rights Commission, stated in Article 28G Paragraph (2) of the 1945 Constitution, "Everyone has the right to be free from torture or treatment 
that degrades human dignity and has the right to obtain political asylum from another country". The purpose of Article 28G Paragraph (2) of the 1945 Constitution is not to justify the existence of Indonesian who are subjected to torture, and/or acts that are inhumane and demeaning human dignity or citizens. In addition, Article 33 Paragraph (1) of Law Number 39 of 1999 on Human Rights stated, "Everyone has the right to be free from torture, punishment or cruel, inhuman, degrading and degrading treatment of humanity". The National Human Rights Commission of the Republic of Indonesia recommends to the government if the use of chemical castration might be very selective and limited, and should go through a strict screening process. (Komnas HAM RI, 2021)

Indria Fernida, a human rights activist who works as Thematic Program Coordinator at Asia Justice and Rights (AJAR) Indonesia, argues that chemical castration is a violation of international human rights law as a form of torture, and other cruel, inhuman, or degrading treatment or punishment, or degrading human dignity and violating the right to life. The provision on chemical castration is a step backward for the Indonesian government which has ratified the International Covenant on Civil and Political Rights. (Institute For Criminal Justice Reform (ICJR), 2012b). In 2005 and the International Convention Against Torture and Other Cruel, Inhuman or Degrading Treatment or Punishment in 1998. (Institute For Criminal Justice Reform (ICJR), 2012a). As a nation party, the Indonesian government must comply with the implementation of these two human rights instruments. (Indria Fernida, 2016)

If human rights activists stated that chemical castration is a form of torture that is contrary to human rights, then criminal law experts have a different opinion. Amira Paripurna, a criminal law expert at the Faculty of Law, Universitas Airlangga, stated that chemical castration is not against human rights. Before the perpetrator is subjected to chemical castration, a clinical assessment should have done to provide a diagnosis regarding the offender could have sexual intercourse with a child subject to chemical castration. Clinical assessment is regulated in Article 7 Paragraph (2) of Government Regulation Number 70 of 2020 on Procedures for Implementing Chemical Castration, Installation of Electronic Detection Devices, Rehabilitation and Announcement of the Identity of Perpetrators of Sexual Violence Against Children, which says "Clinical assessment as referred to in Paragraph (1) include:

a. clinical and psychiatric interviews;

b. physical examination; and

c. supporting investigation".

The following is an understanding of clinical interviews, psychiatric interviews, physical examinations, and supporting examinations: 
a. Clinical interview is a process to obtain information about the physical health condition and mental health of the perpetrator for the purpose of preliminary/interim clinical decisions regarding the convict's health problems.

b. Psychiatric interview is an interview technique to assess the mentality of the convict in the form of structured or unstructured questions without the help of tools.

c. Physical examination is a process to determine if there are physical abnormalities of the convict.

d. Supportive examination is a series of medical examination processes for certain indications in order to obtain complete medical conclusions.

Chemical castration is carried out in the stage of psychiatric medical treatment that has gone through a medical assessment, then it is considered as a rehabilitation of the perpetrator and does not conflict with human rights. As the psychiatric treatment is an action that is carried out based on the human aspect to treat sexual disorders suffered by the perpetrator. (Nikmatus Sholikhah, 2021). After the implementation of chemical castration on perpetrators of sexual intercourse with children, in the next 3 (three) months, rehabilitation would be carried out. In accordance with Article 19 Paragraph (1) Government Regulation Number 70 of 2020 stated that, "Rehabilitation as referred to in Article 18 Paragraph (1) begins to be given no later than 3 (three) months after the implementation of chemical castration". In Article 18 Paragraph (1) of Government Regulation Number 70 of 2020 it is stated that, "Rehabilitation is given to perpetrators of sexual intercourse who are subject to chemical castration in the form of:

a. psychiatric rehabilitation;

b. social rehabilitation; and

c. medic rehabilitation".

Rehabilitation is an effort to restore physical, psychological, social, and spiritual conditions to perpetrators so that they are able to carry out normal daily life activities, while the meanings of psychiatric rehabilitation, social rehabilitation, and medical rehabilitation, are:

a. Psychiatric rehabilitation is an effort to restore mental health and improve skills to be able to carry out activities of daily living.

b. Social rehabilitation is a process of re-functionalization and development to enable a person to be able to carry out his social functions properly in community life.

c. Medical rehabilitation is an effort to provide comprehensive, coordinated medical services that are medical, social, educational and vocational to achieve optimal functional abilities in people's lives. 
Professor of Criminal Law, Faculty of Law, Airlangga University, Didik Endro Purwoleksono also believes that chemical castration is not against human rights, with several arguments as follows. (Didik Endro Purwoleksono, 2019) :

1. That the nature of the perpetrator is recidive, which means he repeats the act of sexual violence

a. The victim factor is one of the reasons for chemical castration, because:

b. It is possible to be traumatized for life;

c. It is possible that children, as victims of sexual violence, could become perpetrators of criminal acts of sexual violence against children in the future;

d. Children as the next generation must be saved from violence or threats of violence forcing children to have intercourse with them or with other people;

e. Many cases of children become victims of criminal acts of human trafficking.

2. Chemical castration must be accompanied by rehabilitation. This shows that the law requires that when a defendant is sentenced to chemical castration, the judge is also obliged to give a decision in the form of rehabilitation to the perpetrator. Thus, it is hoped that the perpetrators can be made aware of their behavior.

3. As the theory of the Balancing Theory of Punishment stated by Didik Endro Purwoleksono, in order to get a balance of punishment for the perpetrators of criminal acts, the victims also need to get attention. This means, not only seeing the human rights of the perpetrator, but the judge must also look at the rights of the victim or victims, before imposing chemical castration. (Didik Endro Purwoleksono, 2014)

The same opinion was also conveyed by Edward Omar Sharif Hiariej, Professor of Science Criminal Law, Faculty of Law, Gadjah Mada University. He stated if the chemical castration does not violate human rights, as it is a sanction that is oriented towards corrective justice and rehabilitative justice. Corrective justice is justice-oriented to the perpetrator, which means correcting the wrongdoing of the perpetrator and the perpetrator is sanctioned. Rehabilitative justice is justice-oriented to the perpetrator and the victim, which means that the perpetrator is given rehabilitation or recovery in order his behavior becomes 'normal' again and the victim given rehabilitation or recovery for the trauma suffered. Chemical castration is a legal construction that is facultative in nature, might or might not be imposed (not a requirement), as of the judge in deciding whether the perpetrator of sexual intercourse with a child could be subjected to chemical castration or not, it must be based on information from medical experts. (Melek Hukum Kompas TV, 2021)

The explanations of several criminal law experts above explain that the act of chemical castration does not violate human rights, because the act of chemical castration is not torture but an 
attempt to restore the perpetrator's hormones or libido and the psychic of sexual intercourse with a child so it could return to normal.

Law Number 17 of 2016 concerning Stipulation of Government Regulation in Lieu of Law Number 1 of 2016 concerning Second Amendment to Law Number 23 of 2002 concerning Child Protection and Government Regulation Number 70 of 2020 concerning Procedures for Implementing Chemical Castration Measures, Installation of Detection Devices Electronic, Rehabilitation and Announcement of Identity of Perpetrators of Sexual Violence Against Children has regulated that the implementation of chemical castration accompanied by rehabilitation measures would be monitored by medical experts. Before the judge decides if the perpetrator of sexual intercourse with a child is subject to chemical castration, the perpetrator must be examined by a medical expert. Next, the results or conclusions would be obtained which would be considered by the judge to decide if the perpetrator of sexual intercourse with a child could be subjected to chemical castratio. If the results or conclusions of medical experts indicate that the perpetrator has high hormones or libido, the perpetrator could be subjected to chemical castration in order to normalize the perpetrator's hormones or libido, accompanied by rehabilitation action. If the perpetrator has normal hormones or libido but is mentally disturbed so that he becomes a pedophile. Therefore, the medical expert concludes and gives advice as a judge's consideration so that the perpetrator is given rehabilitation measures to restore his psychology. (halodoc, 2021)

\section{Chemical Castration Actions In Human Rights Perspective Related To Medicine}

Chemical castration is an attempt to manipulate hormones using hormonal drugs aimed at lowering testosterone levels. In 1944, chemical castration was first introduced to reduce pathological sexual behavior in sexual assault recidivists. In 1944, doctors used Diethylstilbestrol on recidivist sexual assault. A few years later, the United States, Canada, and several countries in Continental Europe used Medroxyprogesterone acetate and Cyproterone acetate to reduce sexual fantasies and sexual urges in perpetrators of sexual violence. More modern developments have found if using Luteinizing Hormone Releasing Hormone (LHRH) agonists such as Leuprolide acetate and Goserelin could help in the treatment of paraphilias. (Joo Yong Lee and Kang Su Cho, 2013)

Testosterone is the main hormone associated with libido and sexual function. Several studies have shown that perpetrators of sexual violence have higher sex hormones (androgens) or testosterone and androgen levels correlate with the severity of sexual aggression. Various comprehensive theories report that perpetrators of sexual violence who are given chemical castration could reduce their sexual interest and sexual performance. This makes chemical castration being one of the sanctions for perpetrators of sexual violence against children. 
Medroxyprogesterone acetate, Cyproterone acetate, and LHRH agonists are drugs that are also used in the treatment of prostate cancer. These three types of drugs are known to lower testosterone and estradiol levels. Estradiol itself is an estrogen hormone that could affect bone strength, heart health, and brain function. This shows a link between chemical castration and several diseases, such as osteoporosis, heart disease, and diabetes. Thus, chemical castration could trigger other effects, such as (Kevin Adrian, 2021):

1. Infertility

2. Hot flushes (sensation of heat, sweating, and palpitations)

3. Anemia

4. Depression

5. Increase the risk of breast enlargement in men called gynecomastia.

The impact is caused by chemical castration. It is observed if it could reduce the rights of perpetrators of sexual violence against children, including perpetrators lose the right to be able to reproduce, perpetrators lose the right to have a healthy body, and perpetrators lose the right to have a healthy mentality. However, this could be overcome by taking vitamins, calcium, and anti-bone loss drugs, as well as providing psychotherapy and supervision from medical experts after the perpetrators have undergone chemical castration.

Although chemical castration is considered as eliminating the rights of perpetrators of sexual violence against children, chemical castration has 4 (four) advantages compared to surgical castration. There are (Joo Yong Lee and Kang Su Cho, 2013) :

1. Perpetrators of sexual violence against children who are given chemical castration are still allowed to carry out normal sexual activities, under psychotherapy given.

2. Chemical castration is not permanent, so perpetrators of sexual violence against children could voluntarily accept chemical castration.

3. Chemical castration is a more realistic sanction than an implanted electronic detector or surgical castration.

4. Unlike surgical castration, the effect of anti-libido drugs could be restored after the administration of anti-libido drugs is stopped. There is an assumption that the general public could feel relieved to know that perpetrators of sexual violence against children receive chemical castration, not only as a form of sanctions but also as a form of treatment for their behavior.

Chairman of the Indonesian Doctors Association, Daeng Muhammad Faqih, stated if chemical castration was imposed on perpetrators of sexual violence against children is not a form of punishment but an action, doctors would be glad to help the government. Since chemical castration is not a form of punishment, it is neither violate the Indonesian Medical Ethics Code nor 
cause a conflict of norms in medical ethics. Indonesian Doctors Association hopes that the chemical castration action that will be imposed on pedophile perpetrators in Indonesia, apart from being an additional sanction, also serves as rehabilitation for pedophile perpetrators, as has been done by other countries that first imposed chemical castration enforced, including Poland, England, Argentina and Germany. (Melek Hukum Kompas TV, 2021)

\section{CONCLUSION}

Chemical castration is the act of giving pills or injections of antiandrogen hormones. Chemical castration is regulated in Law Number 17 of 2016 of Stipulation of Government Regulation in Lieu of Law Number 1 of 2016 of Second Amendment to Law Number 23 of 2002 on Child Protection, in the perspective of criminal law it is appropriate to impose sexual violence on perpetrators against children as sexual violence against children is a serious and cruel crime (graviora delicta). The chemical castration action is a double track system, namely the formulation or law formulation that provides criminal sanctions as well as action sanctions.

In the perspective of human rights, chemical castration does not violate human rights. Ever since chemical castration is a sanction that is oriented towards corrective justice and rehabilitative justice so that chemical castration is not only a punishment but also rehabilitation to restore hormones or libido as well as the pedophile's psychology.

\section{SUGGESTIONS}

1. Judges should be more careful in deciding if perpetrators of sexual violence against children deserve chemical castration. The results of clinical assessments from medical experts need to be taken into account for the judge's decision.

2. Human rights activists should be more vocal for law enforcers to consider the meaning of chemical castration for perpetrators of sexual violence against children in accordance with Law Number 17 of 2016 of Stipulation of Government Regulations in Lieu of Law Number 1 of 2016 of Second Amendments to Laws -Law Number 23 of 2002 on Child Protection, apart from being an effect of retaliation, it is also a means of rehabilitation for perpetrators.

\section{REFERENCES}

Adrian, Kevin. (2021). Ini Efek Kebiri Kimiawi Pada Pria.

BBC News. (2016, May 25). Presiden Terbitkan Perppu Kekerasan Seksual Terhadap Anak.

CNN Indonesia. (2021a, January 4). Selain RI, 11 Negara Terapkan Kebiri Kimia untuk Pelaku Cabul. 
CNN Indonesia. (2021b, January 5). IDI Belum Ambil Sikap Jadi Eksekutor PP Kebiri Kimia. CNN Indonesia, "IDI Belum Ambil Sikap Jadi Eksekutor PP Kebiri Kimia”.

Cito, Davide. (2011). The New Delicta Graviora Laws. Ave Maria International Law Journal, 1(1).

Djunaedi, Mochamad. (2020). Pertanggungjawaban Pidana Pelaku Tindak Pidana Suap Di Sektor Swasta.

Farisa, Fitria Chusna. (2021, January 4). PP 70/2020 Terbit, Ini Tahapan Kebiri Kimia terhadap Predator Seksual Anak.

Fernida, Indria. (2016, June 1). Kebiri Kimia: Jalan Pintas Ala Pemerintah.

Halodoc. (2021). Pedofilia.

Hamzah, Andi. (2014). Asas-Asas Hukum Pidana Edisi Revisi. Rineka Cipta.

Hasanah, Nur Hafizal dan Eko Soponyono. (2018). Kebijakan Hukum Pidana Sanksi Kebiri Kimia dalam Perspektif HAM dan Hukum Pidana Indonesia. Udayana Master Law Journal, 7(3), 308-308.

Hiariej, Edward Omar Sharif Hiariej. (2021, January 5). Alasan Hukum yang Membenarkan Pemasangan Chip dan Kebiri Kimia.

Maharani, Dian. (2015, October 22). Yang Terjadi jika Seseorang Dihukum Kebiri. Https://Health.Kompas.Com/Read/2015/10/22/120535623/Yang.Terjadi.Jika.Seseorang.Dihu kum.Kebiri. Dian Maharani, "Yang Terjadi jika Seseorang Dihukum Kebiri".

Marzuki, Peter Mahmud. (2017). Penelitian Hukum Edisi Revisi.

Institute For Criminal Justice Reform. (2012a, May 14). Konvensi Anti Penyiksaan.

Institute For Criminal Justice Reform. (2012b, May 14). Mengenal Kovenan Internasional Hak Sipil dan Politik.

Isnawati, Muridah. (2018). Tinjauan Tentang Hukum Pidana Pemilu Dan Formulasi Pertanggungjawaban Dalam Tindak Pidana. Perspektif Hukum, 18(2), 294-314.

Komnas HAM RI. (2021, February 1). Mengupas Peraturan Pemerintah (PP) Kebiri Kimia dalam Perspektif HAM.

Lee, Joo Yong and Kang Su Cho. (2013). Chemical Castration for Sexual Offenders: Physicians' Views. Journal Of Korean Medical Science, 28(2), 171-172.

Melek Hukum Kompas TV. (2021, April 24). Bagaimanakah Mekanisme Hukuman Kebiri Kimia. Kompas TV.

Prakasa, Satria Unggul Wicaksana. (2017). Perdagangan Internasional Dan Ham: Relasinya Dengan Sustainable Development. Jurnal Hukum Novelty, 1(1), 36-53.

Prasetyo, Teguh. (2010). Kriminalisasi Dalam Hukum Pidana. Nusa Media. 
Putro, Yuliardi Hardjo. (2016, May 4). Kronologi Kasus Kematian Yuyun di Tangan 14 ABG Bengkulu.

Purwoleksono, Didik Endro. (2014). Hukum Pidana. Airlangga University Press.

Purwoleksono, Didik Endro. (2019). Hukum Pidana: Untaian Pemikiran. Airlangga University Press.

Santika, Gita, et al. (2012). Sistem Pidana dan Tindakan "Double Track System" Dalam Hukum Pidana Di Indonesia. Diponegoro Law Review, 1(4).

Sholikhah, Nikmatus. (2021, January 11). Jokowi Teken PP Kebiri Kimia, Pakar Hukum Pidana UNAIR Berikan Tanggapan.

Yustitianingtyas, Levina. (2016). Pertanggungjawaban Pidana Oleh Korporasi Dalam Tindakan Pelanggaran HAM Di Indonesia. Jurnal Hukum Novelty , 7(1), 25-42. 